\title{
Lopinavir/ritonavir is associated with pneumonia resolution in COVID-19 patients with influenza coinfection:a retrospective matched-pair cohort study
}

\author{
Chong Yu ${ }^{1}$, Zhiguo Zhang ${ }^{1}$, Yujiao Guo ${ }^{1}$, Jing Shi $^{1}$, Guangchang Pei $^{1}$, Wenhui Liao ${ }^{1}$, Ying \\ $\mathrm{Yao}^{1}$, and Rui Zeng ${ }^{1}$ \\ ${ }^{1}$ Huazhong University of Science and Technology Tongji Medical College
}

May 25, 2020

\begin{abstract}
Background: Little is known about whether coinfection of other respiratory tract viruses contributes to severity of COVID-19 pneumonia. Methods: We retrospectively studied 128 hospitalized patients with COVID-19 pneumonia (64 cases co-infected with influenza A/B vs 64 negative influenza cases via pair-matching on age, sex, and days from onset of symptom). Results: Among 64 co-infected patients, 54 patients (84.4\%) had co-infected with influenza A, and 10 (15.6\%) with influenza B. The percentages for the severity of pneumonia on admission of the two groups, i.e., with influenza infection and without, were similar $(\mathrm{P}=0.945)$. The median duration (days) of viral shedding time from admission was longer for patients with influenza infection (17.0 day) than those without influenza infection $(12.0$ day) $(\mathrm{P}<0.001)$. However, the progression of lung $\mathrm{CT}$ in four weeks after onset of symptom were similar in both groups. The multivariable Cox proportional hazards model showed that the HR of pneumonia resolution on CT scans was $0.869(\mathrm{P}=0.612)$ for patients with influenza $(95 \% \mathrm{CI} 0.505,1.495)$ compared with patients without influenza, while the HR of resolution in lung involvement was $1.878(\mathrm{P}=0.020)$ for patients with lopinavir/ritonavir, compared with patients without lopinavir/ritonavir (95\% CI 1.103, 3.196). Patients who were treated with lopinavir/ritonavir presented with faster pneumonia resolution in two weeks after symptom onset both in the whole cohort $(32.4 \%$ vs $13.8 \%$, $\mathrm{P}=0.036)$ and in influenza co-infected group (37\% vs $1 \%, \mathrm{P}=0.001)$. Conclusions: Lopinavir/ritonavir eliminated the difference of lung involvement between influenza co-infected and non-infected groups, indicating lopinavir/ritonavir is associated with pneumonia resolution in COVID-19.
\end{abstract}

\section{Hosted file}

Manuscript.doc available at https://authorea.com/users/325998/articles/453914-1opinavirritonavir-is-associated-with-pneumonia-resolution-in-covid-19-patients-with-influenzacoinfection-a-retrospective-matched-pair-cohort-study

\section{Hosted file}

Table 1.doc available at https://authorea.com/users/325998/articles/453914-lopinavirritonavir-is-associated-with-pneumonia-resolution-in-covid-19-patients-with-influenzacoinfection-a-retrospective-matched-pair-cohort-study

\section{Hosted file}

Table 2.doc available at https://authorea.com/users/325998/articles/453914-lopinavirritonavir-is-associated-with-pneumonia-resolution-in-covid-19-patients-with-influenzacoinfection-a-retrospective-matched-pair-cohort-study

\section{Hosted file}


Table 3.doc available at https://authorea.com/users/325998/articles/453914-1opinavirritonavir-is-associated-with-pneumonia-resolution-in-covid-19-patients-with-influenzacoinfection-a-retrospective-matched-pair-cohort-study

\section{Hosted file}

Table 4.doc available at https://authorea.com/users/325998/articles/453914-lopinavirritonavir-is-associated-with-pneumonia-resolution-in-covid-19-patients-with-influenzacoinfection-a-retrospective-matched-pair-cohort-study

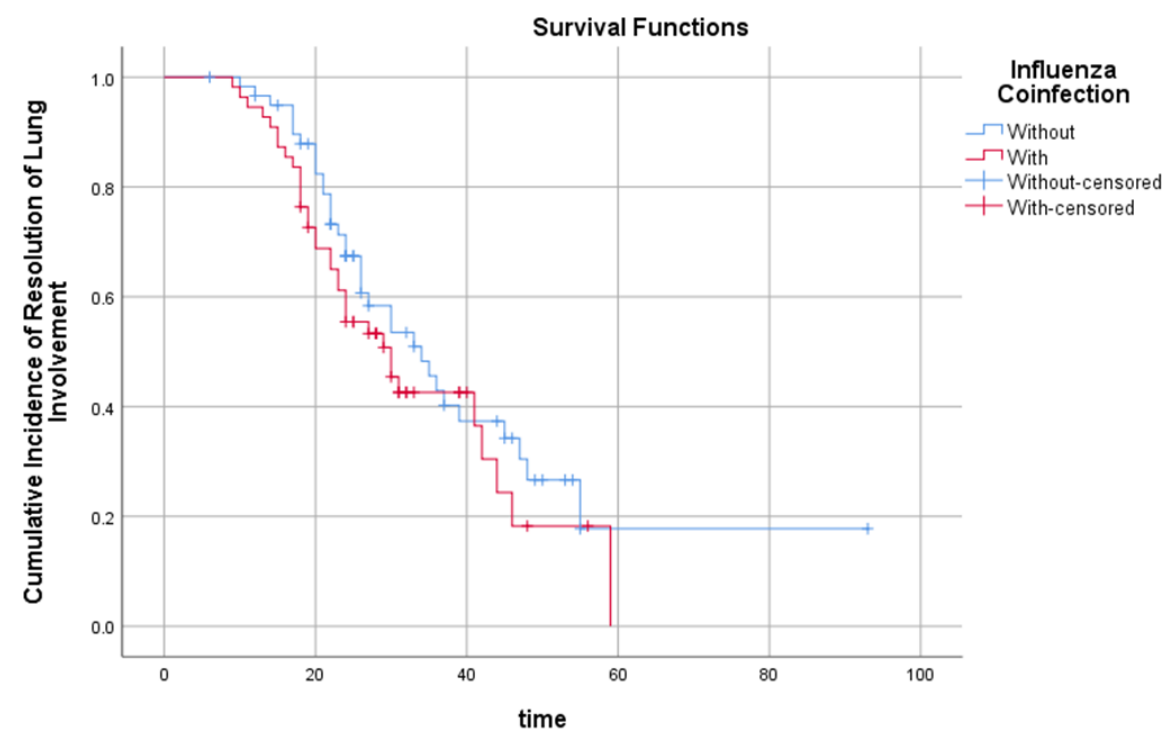

Figure 1. Time (days) cumulative incidence of resolution of lung involvement in patients with influenza co-infected or without.

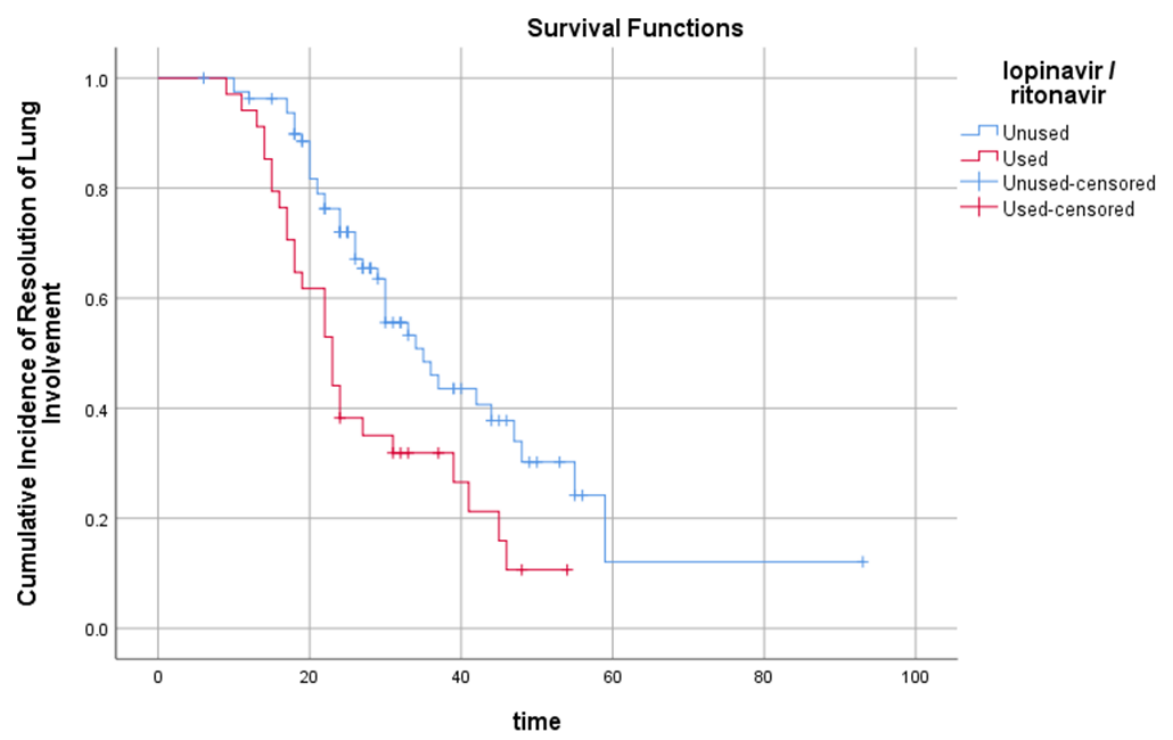

Figure 2. Time (days) cumulative incidence of resolution of lung involvement in patients with lopinavir/ritonavir treatment or without. 